\title{
Clinical evaluation of the urinary sediment after renal allotransplantation
}

\author{
M. PAPAdimitriou, G. D. Chisholm, A. E. KULATIlake, AND \\ R. SHACKMAN \\ From the Urological Unit, Department of Surgery, Hammersmith Hospital, and Royal \\ Postgraduate Medical School, London
}

SYNOPSIS The detection of lymphoid cells by routine examination of the urine after renal allotransplantation has proved to be a useful early indication of rejection. In a study of 36 rejection episodes, $20(56 \%)$ were associated with a significant number of lymphocytes in the $\stackrel{\rho}{工}$ urine. The incidence was much higher when rejection occurred during the first month after $\overrightarrow{0}$ operation $(76 \%)$; lymphocytes were rarely found when rejection occurred after three months. $\bigcirc$ The appearance of lymphocytes in the urine was of particular value for detecting rejection in patients with prolonged oliguria after transplantation.

Although there has been considerable progress in the understanding of immune responses, the diagnosis and management of rejection still remains one of the major problems after organ transplantation. After a kidney allotransplant many clinical symptoms and signs and laboratory investigations have been assessed for the early detection of rejection (Merrill, 1967; Hume, 1967; Russell, 1968). Unfortunately none is sufficiently reliable to be used alone and the clinician must rely on an assessment from as much information as he has available in order to decide on the need for antirejection therapy. This is particularly difficult should there be a period of acute oliguric renal failure after the operation since other causes of decreased kidney function may develop during this period, namely, ureteric obstruction or thrombosis in one of the renal vessels.

Hume, Magee, Kauffman, Rittenbury, and Prout (1963) indicated that one of the earliest signs of rejection was the appearance of renal tubular epithelial cells and lymphocytes in the urine. Other investigators also suggested that the study of urinary sediment was a valuable guide to the fate of a transplanted kidney, especially when the urine was examined daily as a routine procedure (Calne, 1964; Mowbray, Cohen, Doak, Kenyon, Owen, Percival, Porter, Received for publication 29 May 1969. and Peart, 1965; Taft and Flax, 1966; Spencer $\overrightarrow{\vec{O}}$ and Petersen, 1967). Nevertheless, Kline and 3 Craighead (1967) recently reported that cells diagnostic of immunological rejection of the homograft were not observed in their patients.

In this paper we present our experience of the study of urinary sediment after transplantation 3 . during a period of 18 months. Special attention has been paid to the lymphoid cells which appear to play an important role in the rejection processo (Dempster, Harrison, and Shackman, 1964; Porter, 1967).

\section{Material and Methods}

Twenty-eight consecutive patients (13 males and 15 females), who had received a kidney transplant, were studied daily for at least two months after(?) operation. Twenty-two had a cadaveric transplant, 70 five had a live related donor, and one had a freeo unrelated kidney. A timed fresh urine specimen was collected every morning and $10 \mathrm{ml}$ of a welli mixed specimen was spun at $2,000 \mathrm{revs} / \mathrm{min}_{\sigma}$ for five minutes. Depending on the cellular concentration the supernatant was discardedo leaving $0.5 \mathrm{ml}, 1 \mathrm{ml}$, or $2 \mathrm{ml}$, which was carefullys. mixed with the cell button using a pasteur pipette Red cells were haemolysed with an equal volume ${ }^{+}$ 


\begin{tabular}{|c|c|c|c|c|c|c|c|c|c|c|}
\hline No. & Name & Age & $\operatorname{Sex}$ & Donor ${ }^{1}$ & $\begin{array}{l}\text { Acute Tubular } \\
\text { Necrosis }\end{array}$ & & $\begin{array}{l}\text { Time on Peritoneal } \\
\text { or Haemo-dialysis }\end{array}$ & $\begin{array}{l}\text { Rejection } \\
\text { Episodes }\end{array}$ & $\begin{array}{l}\text { Lymphocytes } \\
\text { in the Urine }\end{array}$ & $\stackrel{\Omega}{\bar{\Xi}}$ \\
\hline 1 & A.B. & 18 & $\mathbf{M}$ & C & + & $>$ & 2 months & - & - & مّ \\
\hline 2 & J.B. & 36 & $\mathbf{F}$ & C & + & & 4 days & 2 & 1 & 官 \\
\hline 3 & B.B. & 19 & $\mathbf{F}$ & C & \pm & & - & 1 & - & 음 \\
\hline 4 & J.B. & 21 & $\mathbf{F}$ & $\mathrm{C}$ & + & $>$ & 2 months & 1 & 1 & $\Rightarrow$ \\
\hline 5 & M.C. & 35 & $\mathbf{F}$ & $\mathrm{C}$ & + & & 1 month & 1 & 1 & $\overline{\bar{C}}$ \\
\hline 6 & B.D. & 26 & $\mathbf{M}$ & C & + & & 20 days & 一 & - & $\stackrel{5}{\longrightarrow}$ \\
\hline 7 & M.B. & 38 & $\mathbf{F}$ & $\mathbf{L}$ & - & & - & - & - & ర్ర \\
\hline 8 & J.F. & 17 & $\mathbf{M}$ & $\mathbf{L}$ & t: & & - & 1 & - & б \\
\hline 9 & J.H. & 26 & $\mathbf{M}$ & $\bar{C}$ & $t$ & & 9 days & - & - & $\overline{\overline{0}}$. \\
\hline 10 & D.J. & 36 & $\mathbf{M}$ & C & \pm & & - & - & - & $\frac{\omega}{2}$ \\
\hline 11 & J.K. & 44 & F & $\mathrm{C}$ & + & & 5 days & - & - & $\overline{\mathbb{D}}$ \\
\hline 12 & S.K. & 18 & $\mathbf{M}$ & $\mathbf{L}$ & \pm & & - & 2 & - & 으 \\
\hline 13 & W.M. & 35 & $\mathbf{M}$ & UL & \pm & & - & 1 & 1 & صి \\
\hline 14 & D.O. & 28 & $\mathbf{F}$ & C & \pm & & - & 6 & 3 & $\rightarrow$ \\
\hline 15 & R.P. & 45 & $\mathbf{F}$ & C & + & $>$ & 2 months & 1 & 1 & $\overline{0}$ \\
\hline 16 & B.S. & 32 & $\mathbf{M}$ & $\mathrm{C}$ & + & & 20 days & 3 & 2 & $\rightarrow$ \\
\hline 17 & A.U. & 35 & $\mathbf{M}$ & $\mathrm{C}$ & \pm & & - & 1 & 1 & $\vec{\omega}$ \\
\hline 18 & M.W. & 46 & $\mathbf{F}$ & $\mathrm{C}$ & + & & 14 days & 5 & 3 & హ) \\
\hline 19 & G.G. & 39 & $\mathbf{M}$ & $\mathbf{L}$ & - & & - & 一 & - & $\overrightarrow{0}$ \\
\hline 20 & J.S. & 36 & $\mathbf{F}$ & $\mathbf{L}$ & - & & - & 2 & 2 & $\frac{1}{0}$ \\
\hline 21 & C.F. & 40 & $\mathbf{F}$ & C & + & & 2 days & 1 & 一 & N \\
\hline 22 & D.K. & 26 & $\mathbf{M}$ & $\mathrm{C}$ & + & & 15 days & 1 & - & $\omega$ \\
\hline 23 & L.G. & 49 & $\mathbf{F}$ & $\mathrm{C}$ & + & & 13 days & 1 & - & N \\
\hline 24 & A.D. & 30 & $\mathbf{F}$ & $\mathrm{C}$ & + & & 4 days & 3 & 1 & ق \\
\hline 25 & R.P. & 46 & $\mathbf{F}$ & $\mathrm{C}$ & + & & 10 days & 1 & 1 & 6 \\
\hline 26 & J.D. & 32 & $\mathbf{M}$ & $\mathrm{C}$ & + & & 17 days & - & - & 윽 \\
\hline 27 & J.S. & 37 & $\mathbf{F}$ & $\mathrm{C}$ & + & & 14 days & 2 & 2 & ב \\
\hline \multirow[t]{2}{*}{28} & J.L. & 28 & $\mathbf{M}$ & $\mathrm{C}$ & + & & $\begin{array}{l}30 \text { days } \\
\text { Kidney removed }\end{array}$ & - & - & $\overrightarrow{3}$ \\
\hline & & & & & & & Total & 36 & 20 & 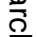 \\
\hline
\end{tabular}

Table I Details of 28 patients followed for at least two months after renal allotransplantation

${ }^{1} \mathrm{C}=$ cadaver, $\mathrm{L}=$ live, $\mathrm{UL}=$ free unrelated kidney.

of $1 \%$ saponin. Total counts were made using an improved Neubauer counting chamber covering a total area of $10 \mathrm{sq} \mathrm{mm}$, five on each side of the chamber. Special care was taken not to have more than 40 cells per sq $\mathrm{mm}$ because if this concentration is exceeded the distribution of cells in the haemocytometer does not follow a Poisson distribution and the observer error is increased (Gadeholt, 1968).

The cell deposit was respun and the supernatant discarded. Smears were then made from the deposit and these were rapidly fixed with a spray fixative and allowed to dry in the air. All smears were stained using a routine haematoxylin and eosin technique. Since cells take up the stain more readily than tissue sections, the times were reduced to five min for haematoxylin and $30 \mathrm{sec}$ for eosin. When suspicious cells were observed and rejection was suspected, duplicate smears were stained by methyl green pyronin for the demonstration of plasma cells and their precursors (Trevan and Sharrock, 1951).

A differential cell count was carried out on each smear reporting the percentages of lymphocytes, polymorphonuclear cells, and epithelial cells (squamous or renal tubular). Special attention was paid to the presence of mucus, bacteria, yeasts, and fungi. The total lymphocyte excretion rate per hour was determined using the volume, the total cell count, and the differential percentage; 50,000 lymphocytes per hour was taken as the upper limit of normal (Spencer, Petersen, and Fjelborg, 1966).

\section{Results}

In 25 of the 28 patients under study there was. evidence of acute tubular necrosis, but only 18 required dialysis after operation (Table I) Thirty-six rejection episodes were diagnosed using other clinical and laboratory measurements (Chisholm, Papadimitriou, Kulatilake, an Shackman, 1969) and confirmed by the responses to treatment. Significant numbers of lymphocytes ie, more than 50,000 per hour, were found in the urine during 20 of the 36 rejection episodess $(56 \%)$. There were three patients (numbers 4 , and 15, Table I) who remained oliguric for more than one to two months after operation. Numbers 4 and 5 were treated successfully for rejection ${ }^{+}$ when the clinical suspicion was supported by raised lymphocyte excretion. In patient no. 1 용 lymphocytes were found in her urine seven days after operation and an open kidney biopsy was performed. Histology showed the characteristio features of rejection but no anti-rejection treato ment was given because there was evidence of a intraperitoneal abscess. The kidney never funcs. tioned satisfactorily and it was removed fout months after transplantation. Another patienit 


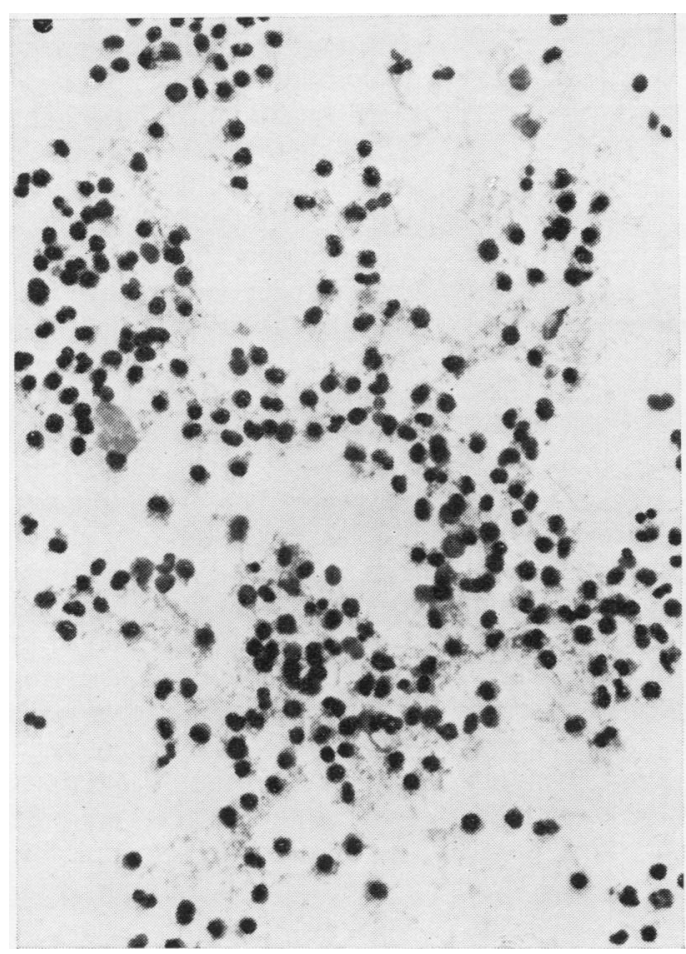

Fig. 1 Urinary sediment during a rejection episode (no. 14, Table I) showing many small and a few large lymphocytes $(H \& E \times 370)$.
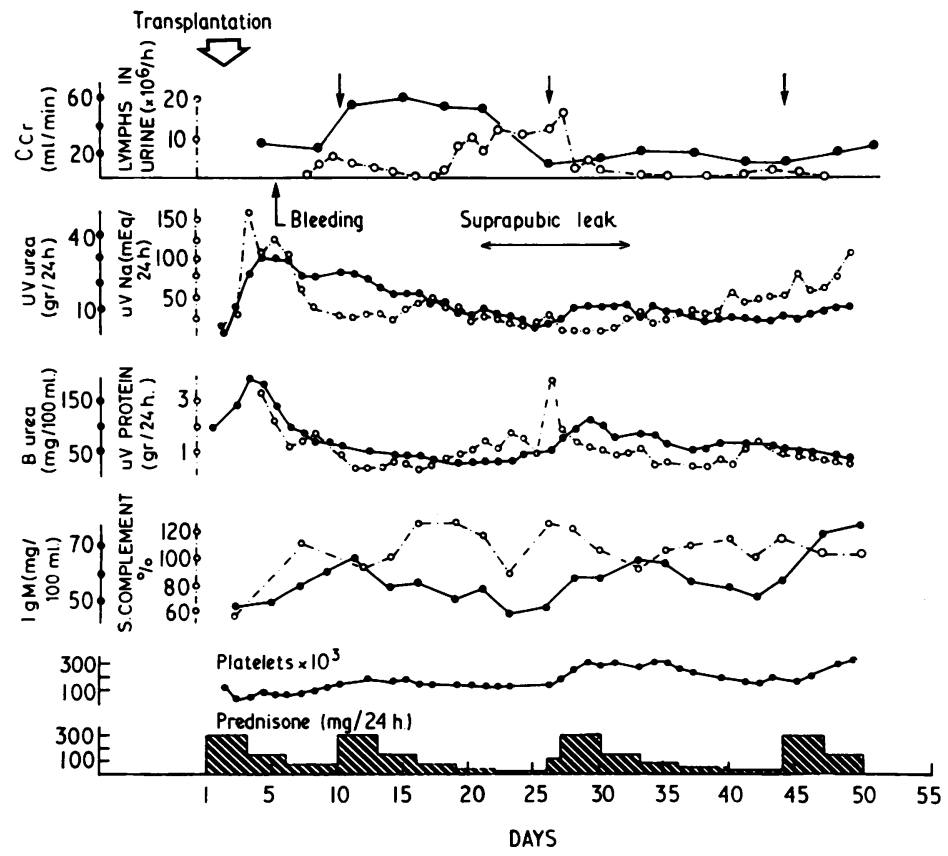

Fig. 2 Postoperative course (no. 14, Table I) showing the changes in urinary lymphocytes and in other measurements that occurred during three rejection episodes (10th, 20th, and 44th days). The presence of a suprapubic urinary leak made the evaluation of urine volumes difficult but the urinary lymphocytes were markedly increased $\left(2 \times 10^{7}\right.$ per hour $)$.

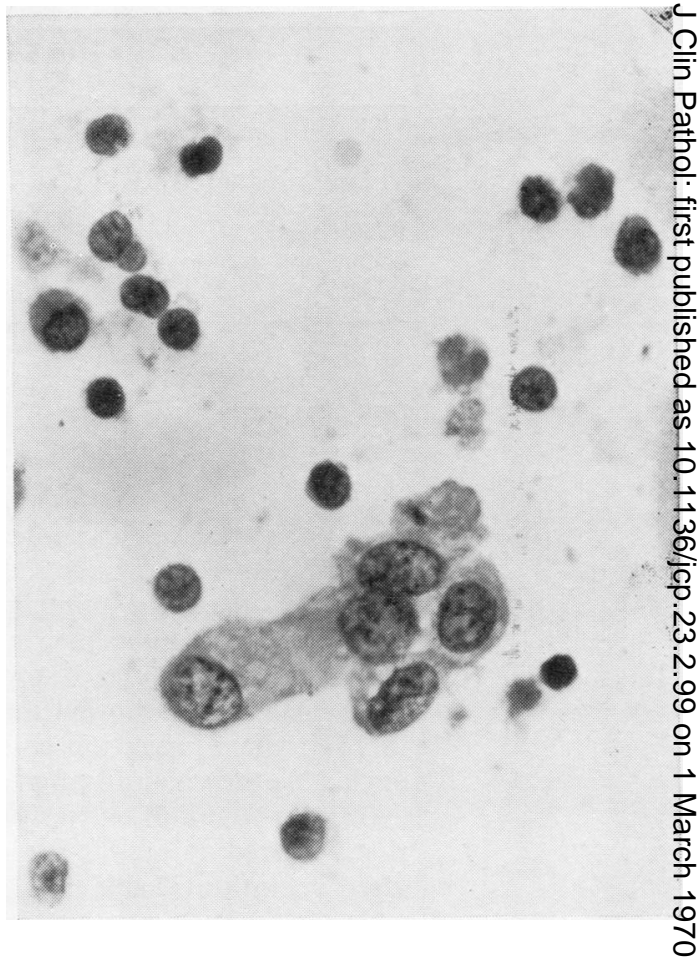

Fig. 3 Urinary lymphocytes and renal tubular epithelial cells during rejection (no. 13, Table I) $(H \& E \times 100)$.

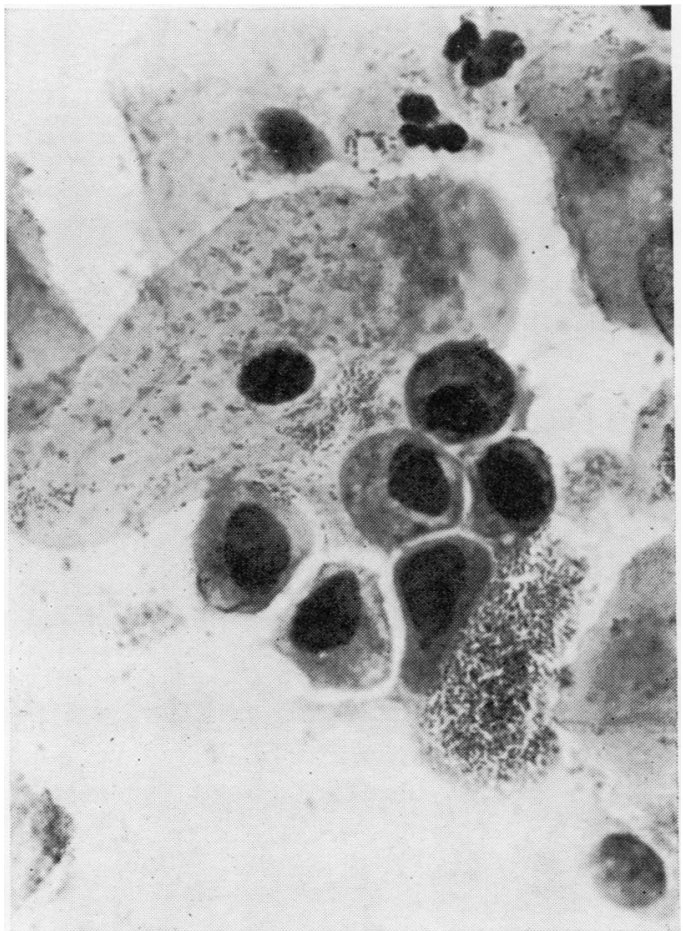

Fig. 4 Epithelioid cells between two large squamous cells seen in the urine (no. 18, Table I) during a second rejection episode $(H \& E \times 1,000)$. 


\begin{tabular}{llll}
\hline & $\begin{array}{l}\text { Time of } \\
\text { Appearance }\end{array}$ & $\begin{array}{l}\text { Rejection } \\
\text { Episodes }\end{array}$ & $\begin{array}{l}\text { Urine } \\
\text { Lymphocytes }\end{array}$ \\
\hline \multirow{3}{*}{ First month } & {$\left[\begin{array}{l}1-10 \text { days } \\
10-20 \text { days }\end{array}\right.$} & 2 & 2 \\
$20-30$ days & 8 & 5 \\
Second month & 11 & 6 \\
Third month & 5 & 6 \\
Fourth-sixth months & 3 & 1 \\
Total & 36 & - \\
\hline
\end{tabular}

Table II Chronological appearance of rejection episodes and lymphocytes in the urine after renal allotransplantation

with prolonged oliguria after operation (no. 1, Table I) also had an open kidney biopsy but this showed evidence of tubular necrosis only and there were no lymphocytes in his urine.

A study of the time of appearance of lymphocytes in the urine showed that these were found in 13 of the 17 rejection episodes that occurred during the first month after operation; lymphocytes were found in only seven of the 16 episodes that occurred during the second and third month after operation (Table II). There was no case where lymphocytes were found in significant numbers that was not associated with a rejection episode.

The typical appearance of the urinary sediment during an acute rejection episode was that of large quantities of small lymphocytes (Figs. 1 and 2). There were cases where the lymphocytes were mixed with tubular epithelial cells (Fig. 3). In rare instances, epithelioid cells were seen during a rejection episode (Figure 4).

\section{Discussion}

It is known that during early rejection episodes after renal allotransplantation there is widespread interstitial oedema and dense focal infiltration of the cortex by mononuclear cells. These are mainly lymphoid cells, the larger ones called immunoblasts and the smaller ones immunocytes. At a later stage these cells are replaced by macrophages and plasma cells (Porter, 1967). These lymphoid cells have a propensity to work their way between tubular cells into the tubular lumen where they accumulate in the urine together with tubular epithelial cells (Russell, 1968). The detection of these cells in the urine has attracted many investigators who have used either methylene blue (Kauffman, Clark, Magee, Rittenbury, Goldsmith, Prout, and Hume, 1964), or the Papanicolaou method (Kline and Craighead, 1967; Taft and Flax, 1966), or the May-GrunwaldGiemsa stain (Spencer and Petersen, 1967). We used the staining method of haematoxylin-eosin and had no difficulty in differentiating polymorphs from mononuclear cells. The latter were further differentiated into squamous epithelial cells and small lymphocytes but thereafter the differentiation was not always so easy. When there was doubt the large lymphoid cell, the renat tubular epithelial cell, and other distorted cello were further differentiated using methyl-green: pyronin as an additional method.

Our finding that the urine in $56 \%$ of the rejece tion episodes was positive for lymphocytes is les than in other reported studies and may be attributed to the use of more rigid criteris Kauffman et al (1964) found significant numbers of lymphocytes in eight of 11 rejection crises. using only the methylene blue technique, however, there is a danger of misdiagnosing tubular epithelial cells as lymphoid cells wit this stain. Spencer and Petersen (1967) foun lymphocytes in the urine in all of the 14 rejection episodes they studied; however, they also reportef a significant number of erythrocytes in the uring at the same time and this would suggest that manळ of the lymphocytes were due to blood contamin? ation. Ten of the 14 rejection episodes studied $b \overrightarrow{\vec{v}}$ Spencer and Petersen were diagnosed during the first 10 days after operation when contaminatio is most likely to occur from the ureterovesicat anastomosis.

It has been suggested that the higher incidence of lymphocytes in the urine during a rejection if the first month after transplantation is due to cellular infiltration. During the late stage afte operation other mechanisms, such as the coating of arterioles and glomerular capillaries with immunoglobulins and complement, are involve and platelet aggregates can be found (Porteß 1967); our findings confirm the high incidence of urinary lymphocytes during rejection in the fir month after transplantation and their low inci dence after that.

Epithelial cells, similar to those shown Figure 4, were not considered as lymphocytès although there is strong evidence that these cells may be derived from lymphocytes (Elves 1966). It has been suggested that the response to first set homografts of solid vascularized tissues may be monitored by the interaction of sma ti lymphocytes with graft antigens and this causes small lymphocytes to develop into large pyroninophilic cells in the regional lymph nodes (Gowans, 1965), but this is still a matter of controversy (Elves, 1966; Porter, 1967).

The appearance of lymphocytes in the urine was found to be one of the earliest signs of rejection and this is in agreement with the results of others (Hume et al, 1963; Spencer and Petersen 1967). Using only clinical symptoms and sign $\$$ the diagnosis of rejection may be delayed by three to seven days (Russell, 1968). Using the criterion of urinary lymphocytes, rejection ma be detected earlier provided that fresh urine $\&$ examined every morning as a routine procedure Where there is prolonged oliguria after operati the appearance of lymphocytes in the urine seen to be particularly helpful in the diagnosis of 
rejection. Rejection was diagnosed in three such patients (nos. 4, 5, and 15) and the two treated with immunosuppressive therapy showed a good recovery as judged by the increase in urine volume, the glomerular filtration rate and the urinary urea, and the disappearance of lymphocytes from the urine.

We wish to thank Mr E. Gains and his staff for technical assistance; Sister J. Jennings and Sister J. Wilkes for their help. Thanks are also due to Miss C. Wade for secretarial assistance.

Requests for reprints should be addressed to $\mathrm{Mr}$ G. D. Chisholm.

\section{References}

Calne, R. Y. (1964). Renal transplantation in man: a review. Brit. J. Surg., 51, 282-293.

Chisholm, G. D., Papadimitriou, M., Kulatilake, A. E., and Shackman, R. (1969). The diagnosis of rejection of renal allotransplants in man. Lancet, 1, 904-906.

Dempster, W. J., Harrison, C. V., and Shackman, R. (1964). Rejection processes in human homo-transplanted kidneys. Brit. med.J., 2, 969-976.

Elves, M. W. (1966). The Lymphocytes, p. 123 and 167, Lloyd-Luke Ltd. London.

Gadeholt, H. (1968). Counting of cells in urine. The variability of haemocytometer counts. Acta med. scand., 183, 9-16.

Gowans, J. L. (1965). The role of lymphocytes in the destruction of homografts. Brit. med. Bull., 21, 106-110.

Hume, D. M., Magee, J. H., Kauffman, H. M., Rittenbury, M. S., and Prout, G. R. Jr. (1963). Renal homotransplantation in man in modified recipients. Ann. Surg., 158, 608-644.

Hume, D. M. (1967). Renal homo-transplantation in man. Ann. Rev. Med., 18, 229-268.
Kauffman, H. M., Clark, R. F., Magee, J. H., Rittenbury, M. S. $\stackrel{\complement}{\complement}$ Goldsmith, C. M., Prout G. R., and Hume, D. M $\Omega$ (1964). Lymphocytes in urine as an aid in the early detection of renal homograft rejection. Surg. Gynec. Obstet., 119, 25-36.

Kline, T. S., and Craighead, J. E. (1967). Renal homotransplanta- $\overrightarrow{\overrightarrow{2}}$ tion. The cytology of the urine sediment. Amer. J. clin.으. Path., 47, 802-806.

Merrill, J. P. (1967). Human tissue transplantation. Adv. Immunol., $\overrightarrow{\overrightarrow{\vec{N}}}$ 7, 275-327.

Mowbray, J. F., Cohen, S. L., Doak, P. B., Kenyon, J. R., Owen, K., Percival, A., Porter, K. A., and Peart, W. S.ర (1965). Human cadaveric renal transplantation; report of twenty cases. Brit. med.J., 2, 1387-1394.

Porter, K. A. (1967). Rejection in treated renal allografts. Symp. Tissue Org. Transplant, Suppl. J. clin. Path., 20, 518-534. त Russell, P. S. (1968). Kidney transplantation. Amer. J. Med., 44, ¿ 776-785.

Spencer, E. S., Petersen, V. P., and Fjelborg, O. (1966). Proc. 3rd. $\vec{\circ}$ int. Congr. Nephrol., Washington. Karger, Basle, Switzerland.

Spencer, E. S., and Petersen, V. P. (1967). The urinary sediment after renal transplantation. Quantitative changes as an $\bigcirc$ index of the activity of the renal allograft reaction. Acta. 0

med. scand., 182, 73-82.
Taft, P. D., and Flax, M. H. (1966). Urinary cytology in renal transplantation: association of renal tubular cells and graft? rejection. Transplantation, 4, 194-204.

$-16$

Trevan, D. J., and Sharrock, A. (1951). A methyl green-pyroninorange G stain for formalin fixed tissues. J. Path. Bact. 윽 63, 326-329. 